

LA-4681

31



27

Determination of Water Evolved from

FFTF Reactor Fuel Peliets 
This report was prepared as an account of work sponsored by the Unixed States Government. Neither the United States nor the United Stotes Atcmic Energy Commission, nor any of their employees, nor any of their contractors, subcontractors, or their employees, makes anv warranty, express or implied, or assumes any legal liability or responsibility for the accuracy, cornpleteness or usefulness of any information, apparatus, product or prosess disclosed, or represents that its use would not infringe privately owned rights.

This report expresses the opinions of the author or authors and does not necessapily reflect the opinions or yiews of the L.os Alamos Scientific Laboratory.

Printed in the United States of America. Available from National Technical Information Service

U. S. Department of Commerce B2865 Port Roval Road

Springtield, Virginio 22151

Price: Printed Copy \$3.00; Microfiche $\$ 0.95$ 
FRO: : IAASL, LOS AIAANOS, NEW MEXICO

SUBJECT: ILA-4681

Enclosed are copins of a Fest licen-ar Rort for distribution in accordance with TID-t500, Standard Distribution Ljst for Unelassicicu Reports. Also enclosed are 47 copics for distribution to the Unitcd Kingdon and EuRATOM. 


\title{
LA.4.681
}

UC- 80

ISSUED: July 1971

This mpport was propared as an account of work sponcored by the United States Coyernment. Neither the United States nor the United States Atomic Enery Cominiselon, not any of their employees, not any of their critrictore, aubcontractiors, or their employees, makes sny warninty, express or implled, or asumes any makes iny warnaty, expreas or implied, or asumes any pleteness or usefulnes of any information, apparatus, product or process disclosed, or represents that its wse would not infringe privately owned rights.

\section{Determination of Water Evolved from FFTF Reactor Fuel Pellets}

by

\author{
Donald E. Vance \\ Maynard E. Smith \\ Glenn R. Waterbury
} This work was sponsored by the Fuels and Materials Branch of the Division of Reactor Deve 'opment and Technology
of the U. S. Atomic Energy Commission. 


\title{
DETERMINATION OF WATER EVOLVED FROM
}

\author{
FWTF REACTOR FUEL PELLETS
}

by

Donald E. Vance, Maynard E. Smith, and Glenn R. Waterbury

\begin{abstract}
Water evolved from FFTF reactor fuel pellets at $400^{\circ}$ is measured by sweeping it with a stream of dry argon through an electrolytic moisture monitor and integrating the monitor response electronically. The moisture monitor is calibrated by injectir.g measured quantitieg of hydrogen gas into the system. The hydrogen is oxidized to water by copper oxirle at $500^{\circ}$ and measurer iy the roolsture monitor. The relative standard devis.tion is $4 \%$ at the $6 ; \mathrm{g} / \mathrm{g}$ level and increases to $19 \%$ at the $1 \mu \mathrm{g} / \mathrm{g}$ level in samples weighing al out $1.5 \mathrm{~g}$.
\end{abstract}

\section{INT?ODUCTION}

A property that is important to the use of sintered mixed oxides as Fast Flux Test Fa.cility (FFTFi reactor fuels is the quantity of gas, including water vapur, arivived at reactor operating temperatures. Published results Indicate that essentially all of the water is evolved at $700^{\circ}$ from plutonium dioxide ${ }^{1}$ and at $300^{\circ}$ from uranium plutonium dioxide. ${ }^{2}$ Results of an investigation described in this report show that $400^{\circ}$ is a suitable temperature to evolve water quantitatively from sintered uranium plutonium dioxide pellets.

Moisture monitors are used to measure small concentrations of water in a flowing gas stream, and integration of the monitor signal provides a quantitative measure of the total amount of water. This information and equipment was used when constructing an apparatus to heat a sintered uranlum plutonium dioxid $a$ pellet $2: 400^{\circ}$ and to measure the evolved water as it was swept through a moisture monitor. This report describes the apparatus, its calibration and testing, and the reliability of the measurements.

\section{APPARATUS AND REAGENTS}

A. Apparatus

Desiccator, with anhydrous magnesium ferchlorate drying agent.

Drying tower, metal, 30 in. long by 2.5 in. diam, filled with anhydrous magnesinm perchlorate. A glas s wool plug in each end contains the reagent dust.

Electronic data-acquisitton system, InfotronIcs Corporation, magnetic tape racorder Model CRS-42RSD, magnetic tape playback Mudel CRS140, digital electronic integrator Model CRS-100, and a Teletype Corporation Teletype Model 33.

Any other integrating device capable of measuring areas under curves with a relative standard deviation of $2 \%$ or less is acceptable.

Furnace tube, fused-silica, for heating samples (Fig. 2). This tube is connected to the moisture monitor by $0.125-i n$. stainless steel tubing (Fig. 1).

Furnace tube, nickel, $16 \mathrm{in}$. long and 1,125

in. diam, fitted with suitable end caps and connectors. The tube is packed with ${ }^{238_{\mathrm{U}}} \mathrm{U}$ turnings and a plug of copper' screen is placed in each end. 


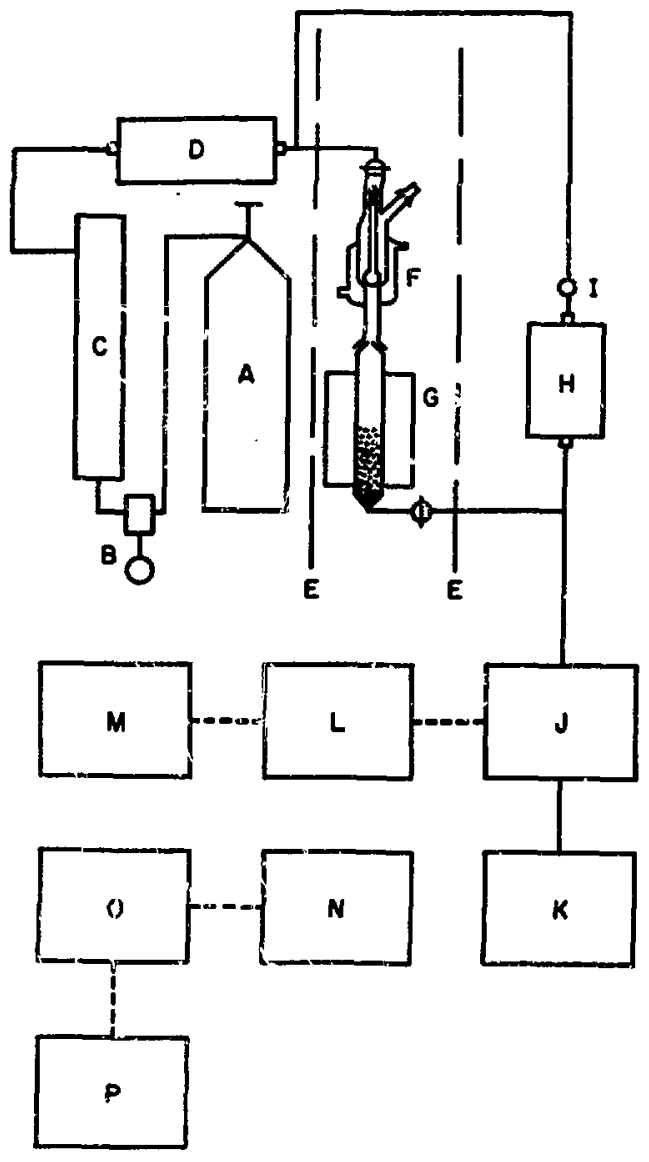

Fig. 1. Water measurement apparatus, A, argon tank with regulator; $B$, low-pressure regulator; C, drying tower; $D$, uraniumfilled furnace tube; $E$, gloved entiusure walls; F, sample dropper; G, sfmple furnace and tube; $H$, cupric oxide-fllled tube and furnace; I, gas chromatographic septum; $\mathcal{Y}$, moisture monitor; $K$, vacuum pump; L, tape recorder; $M$, recolder, -0.5 to $+10 \mathrm{mV} ; \mathrm{N}$, tape playback; 0 . integrator; $P$, recorder, -0.2 to $+1 \mathrm{mV}$.

Furnace tube, stainless ateel, 16 in. long and 1.125 in. diam, fitted with suitiole caps and connectors. The tube is filled with wire-iorm cupric oxide that is held in place by a copper wool plug in each end and connected to the moisture monitor by 0,125-in. stainless steel tubing (Fig. 1).

Gloved enclosure, suitable for handling plutonium oxide. Only the sample dropper and fusedallica furnace tube are contatned in this enclosure.

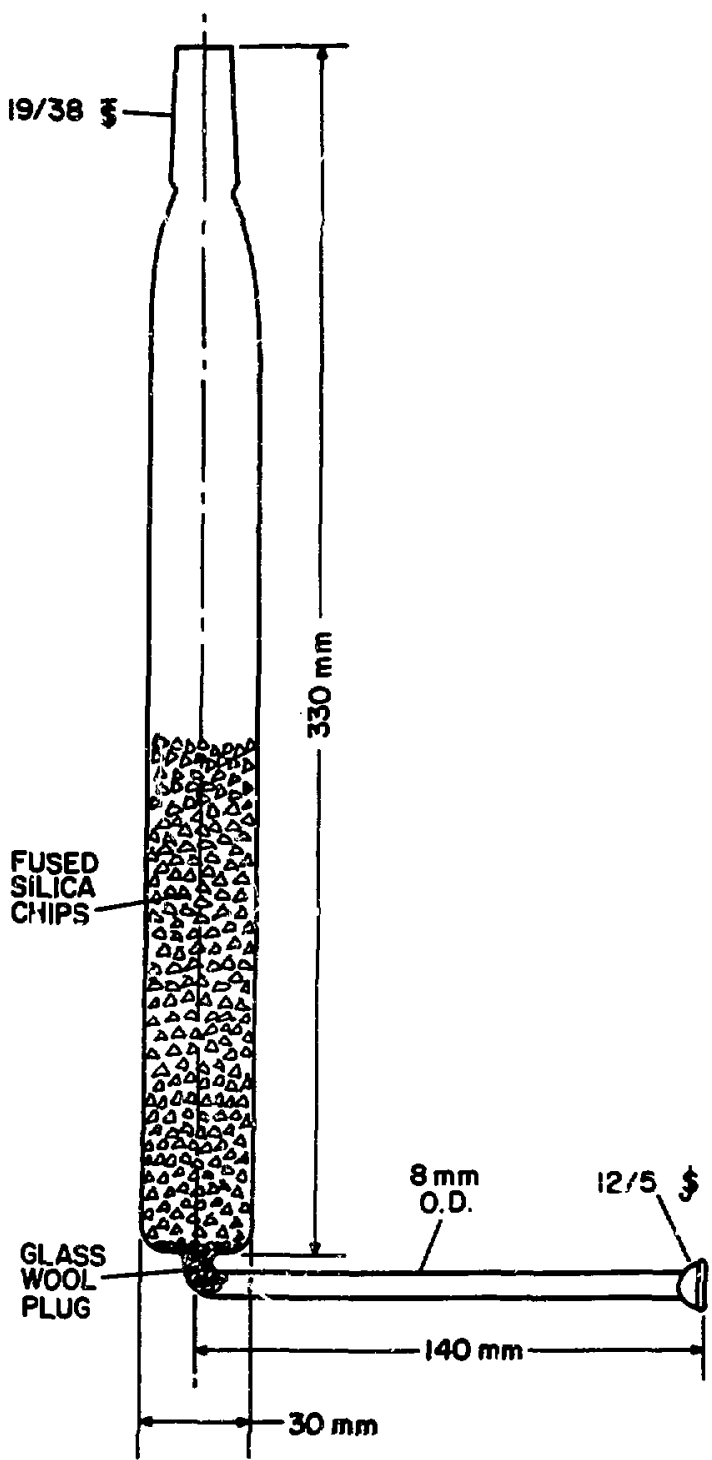

Fig. 2. Fuszd silica furnace tube for heating samplez.

Heating tapes, heavlly insulated, Briskeat or equivalent, for heating the condult from the copper oxide and sample furnace tubes to the moisture monitor, one 6-ft length and one 2-ft length required.

Mass spectrometer, Consoltdated Electrodynamics Corporation, Model 21-620, or equivalent.

Moisture monitor, Ccnsolidated Electrodynamics Corporation, Model 26-303, or equivalent. Regulator, high pressure, one required, Victor Equipment Company, or equivalent.

Regulator, low pressure, with a range of 0 to $50 \mathrm{in}$. of water, Moore Products Company. 


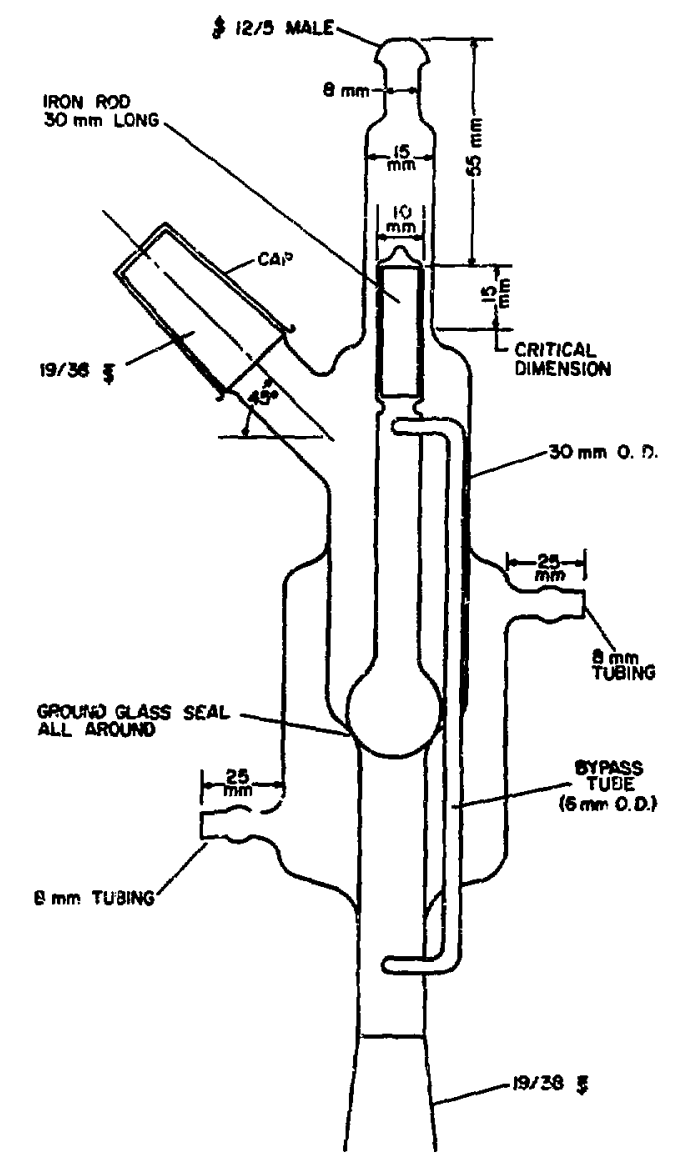

Fig. 3. Sample dropper.

Model 40-2, or equivalent regulating device.

Resistance furnaceg, tube type, 1,25-in. $i_{0} d$. . Hevi Duty Electric Company. Type 70, or equivalent. One furnace 8 in. loug and two furnaces 12 in. long are required.

Saniple dropper, water cooled, borosilicate glass (Fig. 3). A solenoid fitted around the outside of the top tube magnetically raises the iron rod and the attached glass seal when an electric current is passed through the coil.

Septum, gas chromatographic, Hamilton Company, or equivalent.

Strip-chart recorders, one having a range of -0.5 to $+10 \mathrm{mV}$ and one having a range of -0.2 to +1 wV, Minneapolis-Honeyweli, or equivalent. (The recorder having a range of -0.2 to $+1 \mathrm{mV}$ is needed for the data processing system described in this report.)
Syringe, gas chromatographic, 10- $\mu l$ and 25 $\mu \ell$ capacity, Hamilton Company, or equiva:ent.

Thermocouple, having a range of 0 to $1000^{\circ}$, type K, Cromel-Alumel, or equivalent.

Tubing, stainless steel, 0, 125 in.; and copper, 0.25 in.; with Swagelok und hard solder fittings.

Vacuum pump, Welch Duo-Seal, Model 1400B, or equivalent.

Variable transformers, $10 \mathrm{~A}$, five required.

Wet Test Meter. Precision Scientific Company, or equivalent.

\section{B. Reagents}

Argon, tank.

Cupric oxide, wire-form, reagent grade. Hydrogen, tank.

Magnesium perchlorate, anhydrous, rea gent grade. ted ${ }^{238} \mathrm{U}$.

Uranium turnings, normal uranium or deple-

\section{SAMPLE PREPARATTON}

Inspect the sample for obvious impurities, such as lint, and remove any foreign material. Dry the pellets at $110^{\circ}$ for $1 \mathrm{~h}$ and stcre in a desiccator over magnesium perchlorate untll weighed and anciyzed.

\section{OPERATING CONDITIONS}

a. Argon flow rate; $100 \mathrm{ml} / \mathrm{min}$, regulated by needle valve at the cell exit in the moisture monitor.

b. Uranium-fulled furnace tube: $650^{\circ}$.

c. Cupric oxide-fliled furnace tube: $500^{\circ}$.

d. Sample furnace tuibe: $400^{\circ}$.

e. Data acquisition system: recording speed, 1.875 in. /sec; digital filtering, 800; false trip reject, on; level sensing, 400; shoulder printout, off; noise rejection, 5; peak rate; 10; slope sensitivity, 3 ; baseline tracking rate up, 60, down, 200.

\section{RECOMMENDED PROCEDURE}

CAUTON: Health and safety rules for handling radioactive materlals must be rigldiy followed, and edequate protection for the operator must be en- 
sured by using suitable gloved enclosures and protective clothing.

\section{A. Calibration}

1. Turn on and adjust the equipment to obtain the operating conditions listed above. Start the tape recorder when the baseline on the monitor. Ing strip-chart recorder is stable. Recorl the baseline for 1 to $2 \mathrm{~min}$ for subsequent integration, and Inject a measured quantity of hydrogen with a gas chromatographic syringe through the septum, I (Fig. 3). Record the volume injected, the atmospheric pressure, and the temperature of the syringe to the nearest $0,1{ }^{\mathrm{K}}$ at the time of injection.

2. When the baseline again stabilizes, stop the tape recorder and mount the tape on the tape playback. Electronically integrate tice area under the recorded curve three times, and use the median of the three values in subst guent calculations.

3. Repeat steps 1 and 2 making at least 14 Injectionis between 2 and $20 \mu h$ of hydrogen. Calculate the weight of the vater for each injection by using the equation

$$
\mathrm{W}=0.2885 \mathrm{PV} / \mathrm{T},
$$

where $W=$ micrograms of water formed,

$\mathbf{P}=$ millimeters of atmospheric pregsure at time of injection,

$V=$ microllters of hydrogen injected, and

$\mathrm{T}=$ temperature, $\mathrm{a}_{\mathrm{K}}$, of syringe at time of Inject:on.

4. Plot the micrograms of water vs the median value for the area measured for each injection. Using a least-squaree method, draw the best line through the potnts to obtain a standard curve. (The standard curre, shown in Fig. 4, is a computer plot using a least-squares program.)

\section{B. Sample Analygis}

1. Turn on the cooling water th the sample dropper, remove the dropper cup, load the pellet, position the cap over the port, and flush the cap with argon for at least 30 sec before capping the dropper.

2. When the baseline on the monitoring strip-chart recorder stabilizes (about $3 \mathrm{~min}$ ), start the tape recorder, record the baseline for 1 to $2 \mathrm{~min}$, and drop the pellet.

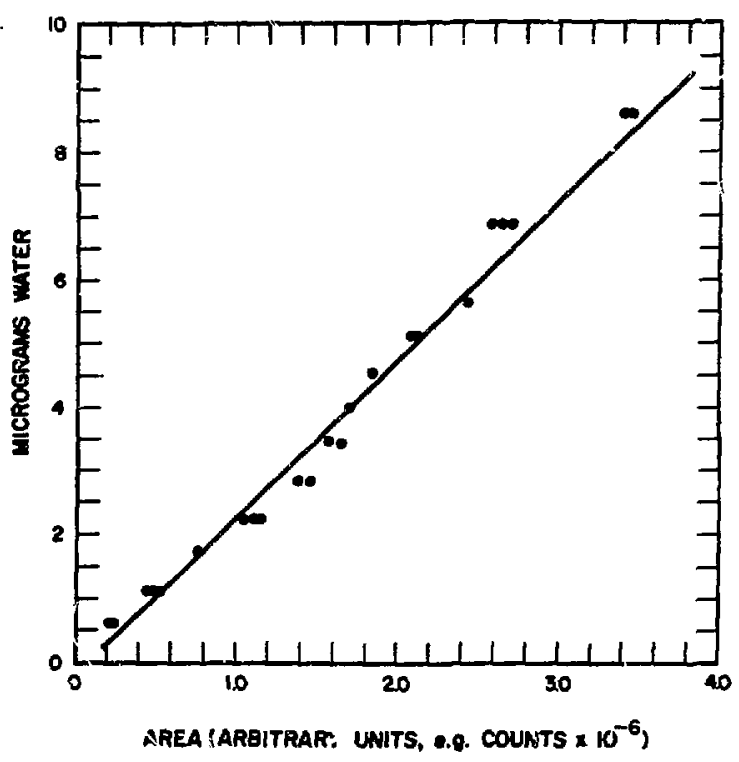

Fig. 4. Micrograms of water vs area.

3. When the baseline on the strip-chart recorder agail stabllizes, stop the tape recorder, mount the tape on the playback unit, and electronically integrate the area unde: the recorded curve three times.

4. Using the median of the three yalues for the curve area, determine the corresponding weight of water from the standard curve.

5. Caleulate the water content of the pellet by dividing the weight of the water in micrograms by the weight of the pellet in grams.

\section{EXPERIMENTAL}

The sampie dropper was equipped with a water-cooled jacket to minimize Ioss of water from the sample while the pellet was held in the dropper. Samples loaded in an uncooled dropper immediately began to evolve water, as evidenced by the trace of the monitoring strip-chert recorder. No evidence of water evolution was found after the waterjacketed dropper was installod.

The flow of argon through the moisture monitor was regulated by a needle valve that ori jinally was on the entrance side. Rapld deterioration (drying) oi the moisture monitor sensing cell occurred because of the resultant low pressure in the cell. Moving the needle valve to the exit side of the moisture monitor increased cell life. 
Two methods for calibrating the apparatus were tried. The first method utilized injections of measured volumes of air, having a known molsture content, through a septum between the sample dropper and the sample furnace. In the second method, measured volumes of hydrogen were injected and oxidized to water by hot cupric oxide. The second method was more precise and convenient. The sensitivity of the mcisture monitor cell gradually decreased, and periodic recalibration of the apparatus was necessary. Injections of hydrogen were also made to check the calibration before each sample was analyzed.

The most suitable temperature for sample analysis was determined by measuring the moisture evolved at predetermined temperature levels from seven fuel pellets. Repeated cycling of an ernpty furnace through the same temperature levels showed that the baseline drift of the moisture monitor was insignificant. The conditions of analysis and results are summarized in Table $I$.

Pellets 1 and 2 had been in direct contact with the laboratory atmosphere 140 to $50 \%$ relative humidity) for at least 6 months. The total amount of water evolved by pellet 1 was probably in excess of $50 \mu \mathrm{g}$ per gram of pellet, about half of which was evolved at earh temperature of evolution. Most of the water was evolved from pellet 2 at $30 n^{\circ}$ and about $1 \mu \mathrm{g} / \mathrm{g}$ was evolved at $360^{\circ}$. Because the amounts of water evolved from these pellets were large and the temperature of evolution was of primary concern, the quantities of water evolved were not measured accurately. Pellets 2 and 3 were predried in an oven at $110^{\circ}$ for $4 \mathrm{~h}$ before analysis to prevent possible overloading and degradation of the moisture monitor sensing ceii aithough this was found to be unnecessary for pellet 3 and subsequent pellets. These pellets had been wrapped in foil and stored in air since receipt by the laboratory. In no case was water evolved at temperatures above $400^{\circ}$, and it was assumed that quantitative evolution of water had occurred at $400^{\circ}$ or lower. As reduction of uranium plutonium dioxide by adsorbed hydrogen to cause high results should not be significant at $400^{\circ}, 3$ this temperature appears to be the most suitable for this analysis.

Data were obtained to show the effects of the storage environment on the adsorption of water by the pellets. Three additional fuel pellets were dried at $600^{\circ}$ for $10 \mathrm{~h}$ in a stream of helium. The pellets were then siored for at least $24 \mathrm{~h}$ in atmospheres having different humidities. The pellets were analyzed in the same manner as pellets 5,6 , and 7 (Table $I$ ). The storage conditions and results of analysis are given in Table II.

TABLE I

MOISTURE EVOLVED FROM URANIM PLUTONIUM DIOXIDE PELLETS AT VARIOUS TEMPERATURES $\left({ }^{\circ} \mathrm{C}\right)$

\begin{tabular}{|c|c|c|c|c|c|c|c|c|c|}
\hline \multirow{2}{*}{$\begin{array}{l}\text { Pellet } \\
\text { No. } \\
\end{array}$} & \multicolumn{9}{|c|}{$\mathrm{H}_{2} \mathrm{O}, \mu \mathrm{g} / \mathrm{g}$} \\
\hline & 200 & 280 & 300 & 360 & 380 & 400 & 500 & 800 & 950 \\
\hline 1 & $\mathrm{ND}$ & NL & 0 & 0 & 0 & 0 & 0 & 0 & 0 \\
\hline 2 & $\mathbf{a}$ & a & ND & 1 & 0 & 0 & 0 & 0 & 0 \\
\hline 3 & a & $\mathbf{a}$ & a & $\mathbf{a}$ & a & 3 & 0 & 0 & 0 \\
\hline 4 & $a$ & $a$ & a & $\mathbf{a}$ & a & 2 & 0 & 0 & 0 \\
\hline 5 & 2 & 0 & 0 & 0 & 1 & 0 & 0 & E & $\mathbf{a}$ \\
\hline 6 & 1 & 0 & 1 & 0 & 0 & 0 & 0 & $\mathbf{a}$ & $\mathbf{a}$ \\
\hline 7 & 22 & 0 & 0 & 0 & 0 & 0 & 0 & a & $\mathbf{a}$ \\
\hline
\end{tabular}

ND - The amount of water was not measured although a significant amount was evolved in this qualitative test.

a - Not included in temperature levels to which this sample was heated. 


\section{TABLF II}

\section{STORAGE CONDITIONS AND RESULTS}

\begin{tabular}{ll}
$\begin{array}{l}\text { Pellet } \\
\text { No. }\end{array}$ & Storage Conditlone \\
\hline 1 & $\begin{array}{l}\text { over } \mathrm{Mg}\left(\mathrm{ClO}_{4}\right)_{2} \text { for } 28 \mathrm{~h} \\
2\end{array}$ \\
$\begin{array}{l}\text { at } 40 \% \text { rolative humldity } \\
\mathrm{fcr} 24 \mathrm{~h}\end{array}$ \\
3 & over $\mathrm{H}_{2} \mathrm{O}$ for $24 \mathrm{~h}$
\end{tabular}

The effects of cifferent storage conditions (humidity) at different laboratories during fuel fabrication and processing were considered. An att6mpt was mada to devalop a procadure of pretreatment before analysis to eliminate these effects. The water was measured in three additionai fuel pellets wrapped in foil and stored in air since their recelpt. The ftrst pellet was not pretreated but was analyzed for watior at $100^{\circ}$ upon removal from storage, When the trace of the monitoring stripchart recorder indicated that all water had been evolved at $100^{\circ}$, the temperature of the analytical furnace was raised rapidly to $200^{\circ}$ and held there until all water was again evolved. The furnace temperature was then raised to $400^{\circ}$ and then to $800^{\circ}$ In the same manner. The second pellet was heated at $110^{\circ}$ in a!r for $4 \mathrm{~h}$, placed in a desiccator with $\mathrm{Mg}\left(\mathrm{ClO}_{4}\right)_{2}$ overnight, and analyzed in the same manner. The third pellet was heated at $110^{\circ}$ for 45 min while under house vacuum, desiccated overnight, and also anslyzed in the same manner. The arnount of water evolved at each temperature is given in Table III. All of the water was evolved at temperatures of $400^{\circ}$ or lower.

These results (Tables $\mathrm{II}$ and III) indicate that comparable storage conditions for the pellets after
Temperature at Beginning of Water Evolution

$200^{\circ}$ $200^{\circ}$
Tctel Water Evolved, $\mu \mathrm{g} / \mathrm{g}$ none evolved 1 3

manufactiure probably should be established. The occurrence of three separate temperatures of water ovolution shown in Table III indicates that the water may be present in three gtates.

For heating the pellets, a fused-silica furnace tube partially fllled with fuged-gilica chipe was chosen, ratuer than a tungsten crucible, to avold possible reaction between water and tungsten. That this reaction might occur was shown by heatIng tungsten powder in a moist argon atmospinere and analyzing the gases for hydrogen, a reaction product, by using a mass spectrometer. Definite reaction was shown after heating at $400^{\circ}$ for 20 min, but no detectable reaction was seen after hearing at $350^{\circ}$ for $45 \mathrm{~min}$.

\section{RELIA BILITY}

Sintered mixed oxides having either known or uniform moisture contents were not available for determining the reliability of the method. The precision of the method was estimated from results obtained for 37 injections of hydrogen. Statistical analysis of the data using a computer program showed that the relative standard deviations ranged from $4 \%$ at the $6 \mu \mathrm{g} / \mathrm{g}$ water level to $19 \%$ at the 1

\section{TABLE III}

\section{EFFECT OF PRETREA TMENT ON WATER EVOLVED}

\begin{tabular}{|c|c|c|c|c|c|}
\hline Pellet & Pretreatment & $\begin{array}{l}\mu \mathrm{g} / \mathrm{g} \mathrm{H}_{2} \mathrm{O} \\
\text { Evolved } \\
\text { at } 100^{\circ} \\
\end{array}$ & $\begin{array}{l}\mu \mathrm{g} / \mathrm{g} \mathrm{H}_{2} \mathrm{O} \\
\text { Evolved } \\
\text { at } 200^{\circ} \\
\end{array}$ & $\begin{array}{l}\mu \mathrm{g} / \mathrm{g} \mathrm{H} \mathrm{H} \\
\text { Evolved } \\
\text { at } 400^{\circ} \\
\end{array}$ & Total \\
\hline 1 & none & $0.5(9 \%)$ & $4.2(76 \%)$ & $0.8(15 \%)$ & 5.5 \\
\hline 2 & $4 \mathrm{~h}$ at $110^{\circ}$, desiccete & $0.2(5 \%)$ & $2.4(65 \%)$ & $1.1(30 \%)$ & 3.7 \\
\hline 3 & $\begin{array}{l}0.75 \mathrm{~h} \text { under vecuum } \\
\text { at } 110^{\circ} \text {, desiccate }\end{array}$ & $0.3(6 \%)$ & $1.8(3 e \%)$ & $2.7(56 \%)$ & 4. 8 \\
\hline
\end{tabular}


$\mu \mathrm{g} / \mathrm{g}$ water level, assuming a 1.5-g sample. Three sintered fuel pellets were analyzed to contain 3.2 , 3.3 , and $4.2 \mu \mathrm{g} / \mathrm{g}$ water. The results were approximately equal to values obtained by other laboratories for these pellets. ${ }^{4}$

\section{ACKNOWLEDGMENTS}

The authors thank Gerald C. Swanson for his assistance, and Charles F. Metz, for his supervision of this work. The computer program to analyze and plot the data was prepared by Faul McWilliems and Janice Norris of the LASL Statistical Services Group.

\section{REFERENCES}

1. J. L. Stakebake and M. R. Dringman, "Desorption from Plutonium Dioxide," RFP-1244, Dow Chemical Company, Rocky Flats Division (1968).

2. W. J. Bartscher, "Coulometrische Bestimmung Des Wassergehaltes Von Uran-Plutoniumoxid and Uranoxid, "EUR-4050 d, Europdisches Institut Fur Transurane (1968).

3. Ce E. Plucinski, "Water and Gas Determination in Mixed Oxides, " Fourteenth Conference on Analytical Chemistry in Nuclear Technology, Gatlinburg, Tennessee, October 13 to $15,1970$.

4. J. E. Rein, R. K. Zeigier, and C. F. Metz, "LMF BR/FFTF Fuel Development Analytical Chemistry Program (Phase II), "LA-4407, Los Alamos Scientific Laboratory (1970). 